Microb Ecol (2003) 45:282-290

DOI: $10.1007 /$ s00248-002-2032-x (C) 2003 Springer-Verlag New York Inc.

\title{
High Diversity among Feather-Degrading Bacteria from a Dry Meadow Soil
}

\author{
F.S. Lucas, O. Broennimann, I. Febbraro, P. Heeb
}

Université de Lausanne, Institut d'Ecologie, 1015 Lausanne, Switzerland

Received: 31 July 2002; Accepted: 7 November 2002; Online publication: 28 March 2003

\section{A B S T R A C T}

The aim of this study was to determine the diversity of cultivable bacteria able to degrade feathers and present in soil under temperate climate. We obtained 33 isolates from soil samples, which clustered in 13 ARDRA groups. These isolates were able to grow on solid medium with pigeon feathers as sole carbon and nitrogen source. One representative isolate of each ARDRA group was selected for identification and feather degradation tests. The phylogenetic analysis of $16 \mathrm{~S}$ rDNA gene fragments revealed that only 4 isolates were gram positives. Two other isolates belonged to the Cytophaga-Flavobacterium group, and the remaining to Proteobacteria. High keratinolysis activity was found for strains related to Bacillus, Cytophagales, Actinomycetales, and Proteobacteria. The 13 selected strains showed variable efficiency in degrading whole feathers and 5 strains were able to degrade maximum $40 \%$ to $98 \%$ of the whole feathers. After 4 weeks incubation, five strains grown on milled feathers produced more than $0.5 \mathrm{U}$ keratinase per $\mathrm{mL}$. Keratinase activities across the 13 strains were positively correlated with the percentage of feather fragmentation and protein concentration.

\section{Introduction}

Wild birds molt once or twice a year and abandoned feathers do not accumulate in nature, suggesting the existence of natural decomposers or users of feathers [19]. Feathers are constituted of almost pure keratin protein (90\%), which is insoluble and undegradable by most proteolytic enzymes [31]. However, some microorganisms possess keratinolytic enzymes, which convert keratin into peptides [21]. Studies of feather-degrading microorgan-

Correspondence to: F.S. Lucas; E-mail: francoise.lucas@ie-zea.unil.ch isms are mostly restricted to animal diseases and to biotechnology for processing large amounts of waste byproduct at poultry-processing plants [19]. So far, only some species of saprophytic and parasitic fungi, thermophilic Actinomycetes, and Bacillus strains have been reported to be able to degrade feather keratin [19]. Most of these strains have been isolated from poultry waste using nutrient-rich medium and have been shown to degrade feathers at $50-60^{\circ} \mathrm{C}$.

The ecological relevance of these thermophilic isolates in natural systems is unknown, but mesophilic bacteria might have a greater impact. Recently using a feather-meal 
medium, Sangali and Brandeli [23] isolated three strains, including two Gram negatives, able to degrade keratin at $30^{\circ} \mathrm{C}$. It is not known how widely the ability to degrade feathers is distributed through the Bacteria because our basic knowledge of bacterial diversity and physiology is biased by limitations of culture methods [12]. Little research has been conducted to examine the impact of keratinolytic microorganisms in nature. Burtt and Ichida [4] found several keratinolytic Bacillus strains on the feathers of wild avian species. The analysis of keratinolytic assemblages could reveal an essential and undescribed community for the recycling of keratin and potentially affecting feather traits in wild birds $[4,7]$. The identification of new feather-degrading isolates is necessary to develop culture-independent methods to analyze such communities. These efforts would also have potential application in biotechnology and fundamental biology.

The goal of our study was to investigate the diversity of cultivable keratinolytic bacteria active in the soil environment under temperate climate. We constituted a collection of feather-degrading soil bacteria using an adequate isolation culture medium. The strains isolated from soil were identified with 16S rDNA phylogeny. Their growth and degradation of feather were compared under controlled conditions. Fragmentation and production of dissolved proteins, amino acids, and keratinases were also analyzed.

\section{Materials and Methods}

\section{Isolation, Purification, and Maintenance of Strains}

In May 2001, feather-degrading strains were isolated from triplicate soil samples collected near the University of Lausanne (Switzerland) in a dry meadow. A volume of $200 \mu \mathrm{L}$ of soil slurry (soil:sterile phosphate buffer $120 \mathrm{mM}, 1: 2 \mathrm{v} / \mathrm{v}$ ) was streaked on feather-meal agar, containing $15 \mathrm{gL}^{-1}$ of ground pigeon feather, $0.5 \mathrm{gL}^{-1} \mathrm{NaCl}, 0.3 \mathrm{gL}^{-1} \mathrm{~K}_{2} \mathrm{HPO}_{4}, 0.4 \mathrm{gL}^{-1} \mathrm{KH}_{2} \mathrm{PO}_{4}$, and $15 \mathrm{gL}^{-1}$ agar and autoclaved $15 \mathrm{~min}$ at $120^{\circ} \mathrm{C}$ [23]. In another approach, UV sterilized pigeon feathers were allowed to degrade 3 weeks in litter bags placed in the first centimeter of the dry meadow soil. They were then collected and placed on the feather-meal agar medium for selection of feather-degrading bacteria. For subculturing, Caso-agar (Merck) medium was used for convenience since feather-meal medium needs handwork to reduce feather into powder. After 5 days of incubation at room temperature, single colonies were picked and transferred on Caso-agar medium. Isolates were purified by repeated subculturing on Caso medium and then stored at $-20^{\circ} \mathrm{C}$ in Caso broth with $15 \%$ glycerol (v/v) until processing.

\section{PCR and Restriction Analysis}

To extract genomic DNA, one colony of each isolate was resuspended in $50 \mu \mathrm{L}$ of TE buffer [22] and boiled for $10 \mathrm{~min}$. Samples were centrifuged $10 \mathrm{~min}$ at $8000 \mathrm{~g}$ and amplification of $16 \mathrm{~S} \mathrm{rDNA}$ by PCR were conducted using $5 \mu \mathrm{L}$ of supernatant. Primers $63 \mathrm{f}$ (5' CAGGCCTAACACATGCAAGTC $\left.3^{\prime}\right)$ and 1389r ( $5^{\prime}$ ACGGGCGGTGTGTACAAG $3^{\prime}$ ), corresponding to Escherichia coli $16 \mathrm{~S}$ rRNA gene position, were used in a $50 \mu \mathrm{L}$ reaction volume according to Osborn et al. [20]. Briefly, PCR products were amplified with $2.5 \mathrm{U}$ of Taq DNA polymerase (Qiagen) and 100 ng of crude DNA. Reactions were initially denatured for $2 \mathrm{~min}$ at $94^{\circ} \mathrm{C}$ followed by 20 cycles of $94^{\circ} \mathrm{C}$ for $1 \mathrm{~min}, 55^{\circ} \mathrm{C}$ for $1 \mathrm{~min}$, and $72^{\circ} \mathrm{C}$ for $2 \mathrm{~min}$, followed by a final extension step of $72^{\circ} \mathrm{C}$ for 10 min. PCR products were quantified using Hoechst dye and a Hoefler fluorimeter (Pharmacia).

Redundant isolates were checked using ARDRA (Amplified Ribosomal DNA Restriction Analysis) patterns [28]. An aliquot of $180 \mathrm{ng}$ of PCR product (63f-1389r fragment) was digested with CfoI (Roche), according to manufacturer instructions. After electrophoresis on $2 \%$ agarose gel, band DNA positions were determined with the software Crosschecker 2.91 (J.B. Buntjer, Wageningen University). Band patterns were then compared by cluster analysis (Euclidean distance, UPGMA method) using the software S-PLUS 2000 (MathSoft, Inc.).

\section{Sequencing and Phylogenetic Analysis}

One representative isolate of each ARDRA group was picked for $16 \mathrm{~S}$ rRNA gene partial sequencing. PCR products obtained with the primer set 63f-1389r (see above) were purified using the columns Wizard PCR preps DNA purification systems (Promega). Sequencing reaction was carried out in a $5-\mu \mathrm{L}$ reaction volume with $15 \mathrm{ng}$ of purified DNA, $1.5 \mu \mathrm{L}$ of $1 \mu \mathrm{M}$ primer $63 \mathrm{f}, 3$ $\mu \mathrm{L}$ of BigDye Terminator 3.0 (ABI Prism, PE Applied Biosystems), and $0.5 \mu \mathrm{L}$ of distilled water. PCR was run for 25 cycles under the following conditions: $96^{\circ} \mathrm{C}$ for $20 \mathrm{~s}, 50^{\circ} \mathrm{C}$ for $10 \mathrm{~s}$, and $60^{\circ} \mathrm{C}$ for $4 \mathrm{~min}$. An ABI PRISM $373 \mathrm{XL}$ DNA sequencer (PE Applied Biosystems) was used for sequencing. Sequences were submitted to GenBank and received the accession numbers AY04487 to AY04492 and AF427156 to AF427162. Close relative accession numbers were Bacillus macroides dhr2 (AF157696), $B$. megaterium DMS 32 (X60629), B. thuringiensis bactisubtil (AF172711), Arthrobacter ilicis DMS 20138 (X83407), soil bacterium P16S841 (AF214140), Cytophaga johnsoniae DSM425 (M59053), Uncultured Cytophagale clone LD3 (AJ007872), Sphingobacterium spiritivorum ATCC33861 (M58778), Unidentified bacterium isolate SS5 (AJ223456), Ochrobactrum grignosense OgA9a (AJ242581), Janthinobacterium lividum BD17-1 (AF174648), Agricultural soil bacterium SI-8, Pseudomonas fragi ATCC4973 (AF094733), P. agmydali LMG 2123T (Z76654), Arsenite-oxidizing bacterium "Alcaligenes fecalis HLE" (AY027506), Stenotrophomonas maltophilia LMG 10857 (AJ131117), and Serratia fonticola DSM4576 (AJ233429). Sequences ranged from 470 to 499 base pairs in length (excluding 


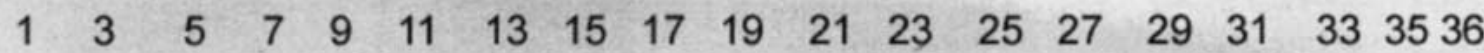

\section{base}

1500

500

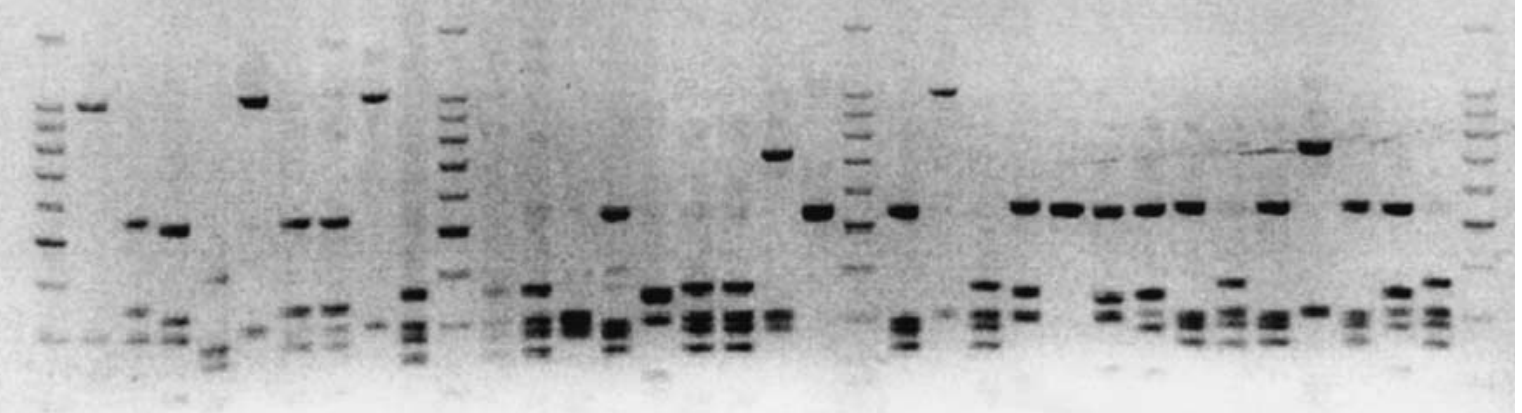

200

Fig. 1. Representative ARDRA gel of feather-degrading isolates. Lanes 1, 11, 21, and 36: 100 bp standard (Promega): Lanes 2 to 10: isolate (is.) $26-2$, is. $B$, is. $28-22$, is. 20 , is. 7 , is. $11-2$, is. $28-21$, is. $28-1$, is. 19 . Lanes 12 to 20 : is. $25-22$, is. $23-1$, is. $3-2$, is. $24-1$, is.

primer sequence), except for isolate J for which we obtained a 259 base pair sequence. To ensure reliable phylogenetic positioning at least $400 \mathrm{bp}$ is desirable and sufficient, however it is possible to use partial sequences to identify organisms or to assign them to well-established phylogenetic groups, as long as the database contains sequences of close relatives [16].

The BLAST algorithm was used to search for homologous sequences in GenBank. Sequences were aligned and compared to similar database sequences using the Genetics Computer Group Inc. package (Madison, Wis.). Phylogenetic trees were inferred from Jukes-Cantor distances using the neighbor-joining method (software Phylip 3.572, [10]); the branching pattern was checked by 1000 bootstrap replicates.

\section{Whole Feather Fragmentation}

To test feather fragmentation by the representative isolates of each ARDRA group, gray pigeon feathers were collected on the two wings from six individuals, on the same row of overwing coverts. Feathers were thoroughly washed with tap water, rinsed 3 times with distilled water, dried overnight at $65^{\circ} \mathrm{C}$, and weighed to the nearest microgram. Mean weight of feathers was $22.072 \pm 0.107 \mathrm{mg}$. Each feather was placed in $8 \mathrm{~mL}$ of saline phosphate buffer and autoclaved $15 \mathrm{~min}$ at $120^{\circ} \mathrm{C}$ [23]. Each isolate was inoculated in 6 replicate tubes. Inoculations were adjusted to a final concentration of $1.6 \times 10^{6}$ cells per $\mathrm{mL}$, after measurement with absorbance at $420 \mathrm{~nm}$. Control tubes were not
C2, is. $25-21$, is. $3-1$, is. $24-25$, is. $24-3$. Lanes 22 to 35 : is. $2-2$, is. $25-1$, is. $2-1$, is. $\mathrm{E}$, is. $\mathrm{N}$, is. $24-2$, is. $8-1$, is. 5 , is. $\mathrm{NF}$, is. $18-2$, is. 1 , is. 4 , is. $28-22$, is. $25-22$.

inoculated. Feather weight was not significantly different between the 14 groups of tubes (analysis of variance, $F_{13,60}=0.18$, $p=0.99$ ). After 3 weeks of incubation at $25^{\circ} \mathrm{C}$ and agitation at $200 \mathrm{rpm}$, the feather medium was filtered on GF/C membranes (Whatman) to collect feather fragments. This temperature was chosen since we aimed to look at the activity of bacteria occurring in temperate climate and isolated at $25^{\circ} \mathrm{C}$. Boetius and Lochte [2] showed that optimal temperature, $\mathrm{pH}$, and salinity of lytic enzymes are adapted to the environmental conditions where the bacteria naturally occur. Membranes were dried overnight at $65^{\circ} \mathrm{C}$ and weighed (dry weight) to the nearest microgram. Remaining feathers and fragments collected on GF/C membrane were reported as the percentage of weight compared to the initial dry weight of the feather. Statistical analysis was performed with the software JMP 4.0.4 (SAS Institute Inc.).

\section{Milled Feather Degradation}

Keratin solubilization was tested using milled feathers. Ventral body feathers from six pigeons were washed, dried as described above, cut in small pieces, and reduced in a coarse powder using a mortar and liquid nitrogen. A quantity of $10 \mathrm{mg}$ of feather powder was resuspended in $5 \mathrm{~mL}$ of saline phosphate buffer and autoclaved as above. For each strain, three tubes were inoculated with $200 \mu \mathrm{L}$ of a suspension of about $1.2 \times 10^{8}$ cell per mL (determined by measuring absorbance at $420 \mathrm{~nm}$ ). Triplicate control tubes were not inoculated. Tubes were incubated 4 weeks 
at $25^{\circ} \mathrm{C}$ with agitation. At the end of the experiment, cultures were prefiltered through GF/C membranes (Whatman) and then through $0.2 \mu \mathrm{m}$ Durapore membranes (Millipore). Filters were discarded and filtrates were conserved to measured dissolved proteins, amino acids, and keratinase:

1. Total protein concentration was quantified with the Bio-Rad protein assay method, according to manufacturer protocol (Bio-Rad) and BSA (bovine serum albumin) as a standard ( $\mu \mathrm{g}$ BSA per $\mathrm{mL}$ ).

2. Amino acids were measured with a ninhydrin colorimetric method [13], using glycine as a standard ( $\mu \mathrm{g}$ of glycine per $\mathrm{mL})$.

3. Keratin azure (Sigma) hydrolyzing activity was estimated according to the method of Santos et al. [24], with $22 \mathrm{~h}$ incubation. Results were expressed as units of keratinase per $\mathrm{mL}, 1$ unit of keratinase being defined as the activity required for 1.0 $A_{595}$ unit increase in $3 \mathrm{~h}$ incubation [24].

Spearman rank correlation coefficients between results from whole and milled feather experiments were calculated using the software JMP 4.0.4 (SAS Institute Inc.).

\section{Results}

\section{ARDRA and Phylogenetic Analysis of Isolates}

A representative ARDRA gel is shown in Fig. 1. Thirtythree isolates were recovered from soil and degraded feathers. Analysis of ARDRA patterns grouped the isolates in 13 clusters (Fig. 2). For sequencing and feather degradation experiments, one random isolate was picked from each cluster: C2, E, J, N, 1, 2-2, 3-1, 3-2, 7, 8-1, 19, 20, and 24-25.

Phylogenetic analysis and identification of the strains are summarized in Figs. $3 \mathrm{~A}$ and $3 \mathrm{~B}$. Based on the percentages of identity in $16 \mathrm{~S}$ rRNA sequences, four isolates were gram positives. The isolates $\mathrm{C} 2, \mathrm{E}$, and $\mathrm{J}$ shared less than $90 \%$ identity and were related to Bacillus species (99.3 to $99.8 \%$ ). Isolate 20 was close to the Actinomycetale Arthrobacter ilicis (99.6\%). Two isolates were related to the Cytophaga-Flavobacterium group: strain 24-25 was related to Cytophaga johnsoniae (98.3\%), and isolate 7 was close to an uncultured Cytophagale clone LD3 (99.2\%). Isolate 3-2 was $100 \%$ identical to an unidentified bacterium isolate SS5, which belongs to the Ochrobactrum genus of the $\alpha$ subdivision of the Proteobacteria. The sequences of strains $\mathrm{N}$ and $2-2$ were respectively $100 \%$ identical to the sequences of Janthinobacterium lividum and the arsenite-oxidizing bacterium Alcaligenes fecalis HLE ( $\beta$ Proteobacteria). Isolates $8-1,19,3-1$, and 1 were related to the $\gamma$-subunit of Proteobacteria. The sequence of isolate 1

\section{Euclidean distance}

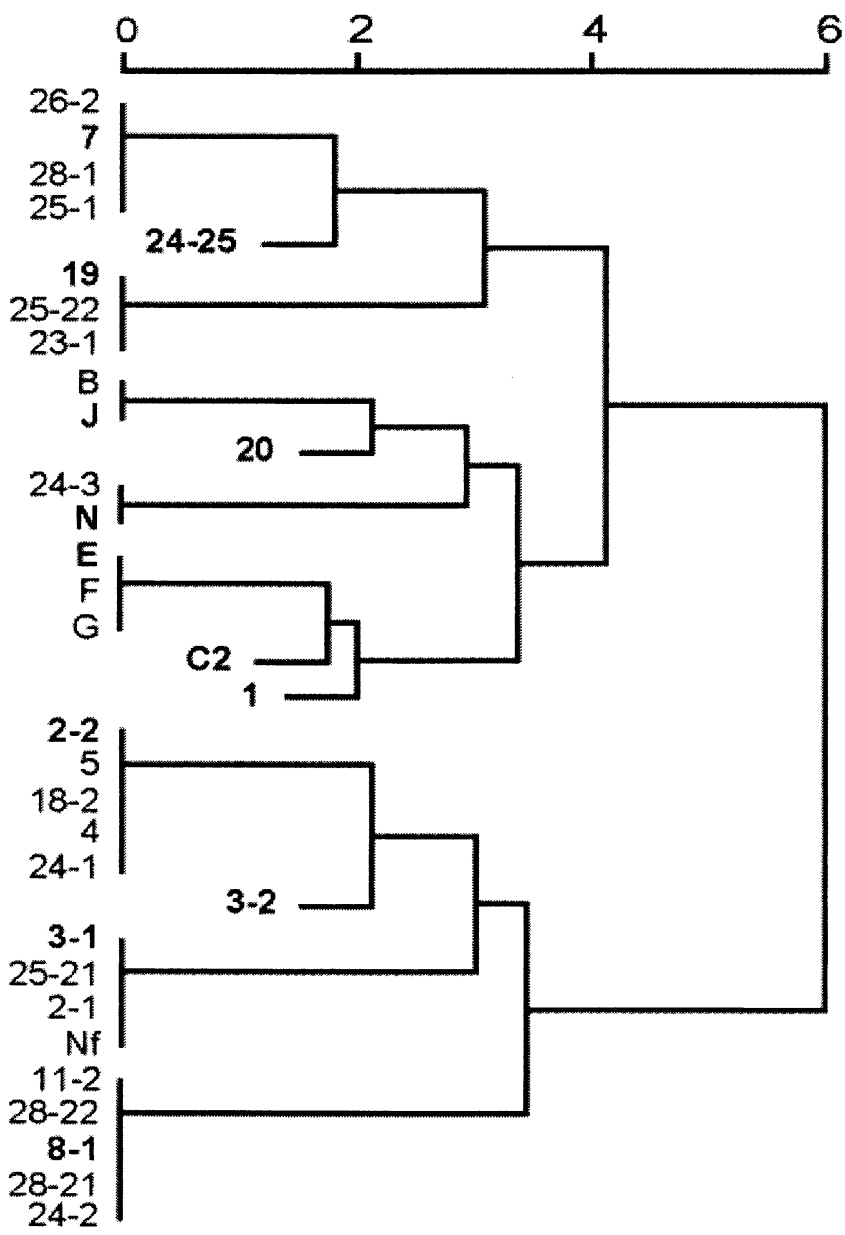

Fig. 2. Ward dendogram generated from ARDRA profiles of 33 isolates. Selected organisms for identification and testing are in bold.

was $100 \%$ identical to the sequence of Stenotrophomonas maltophilia. Isolate 19 shared $99 \%$ identity with isolate 31. Both were related to Pseudomonas species: P. fragi and $P$. agmydali, respectively. Isolate 8-1 was related to Serratia fonticola (99.8\%).

\section{Whole Feather Fragmentation}

After an incubation period of 3 weeks, the fragmentation of feathers differed among replicates (Table 1). The percentage of remaining feather $\left(\chi^{2}=43.9, \mathrm{DF}=13, p<\right.$ $0.001)$, the percentage of GF/C fraction $\left(\chi^{2}=33.6\right.$, $\mathrm{DF}=13, p<0.0014)$, and the concentration of bacteria in liquid medium $\left(\chi^{2}=59.4, \mathrm{DF}=13, p<0.001\right)$ were significantly different among strains. Strains E, J, 24-25, 19, 1, and 20 displayed at least one replicate with a degradation superior to $50 \%$ (Table 1). Growth was higher in strains 


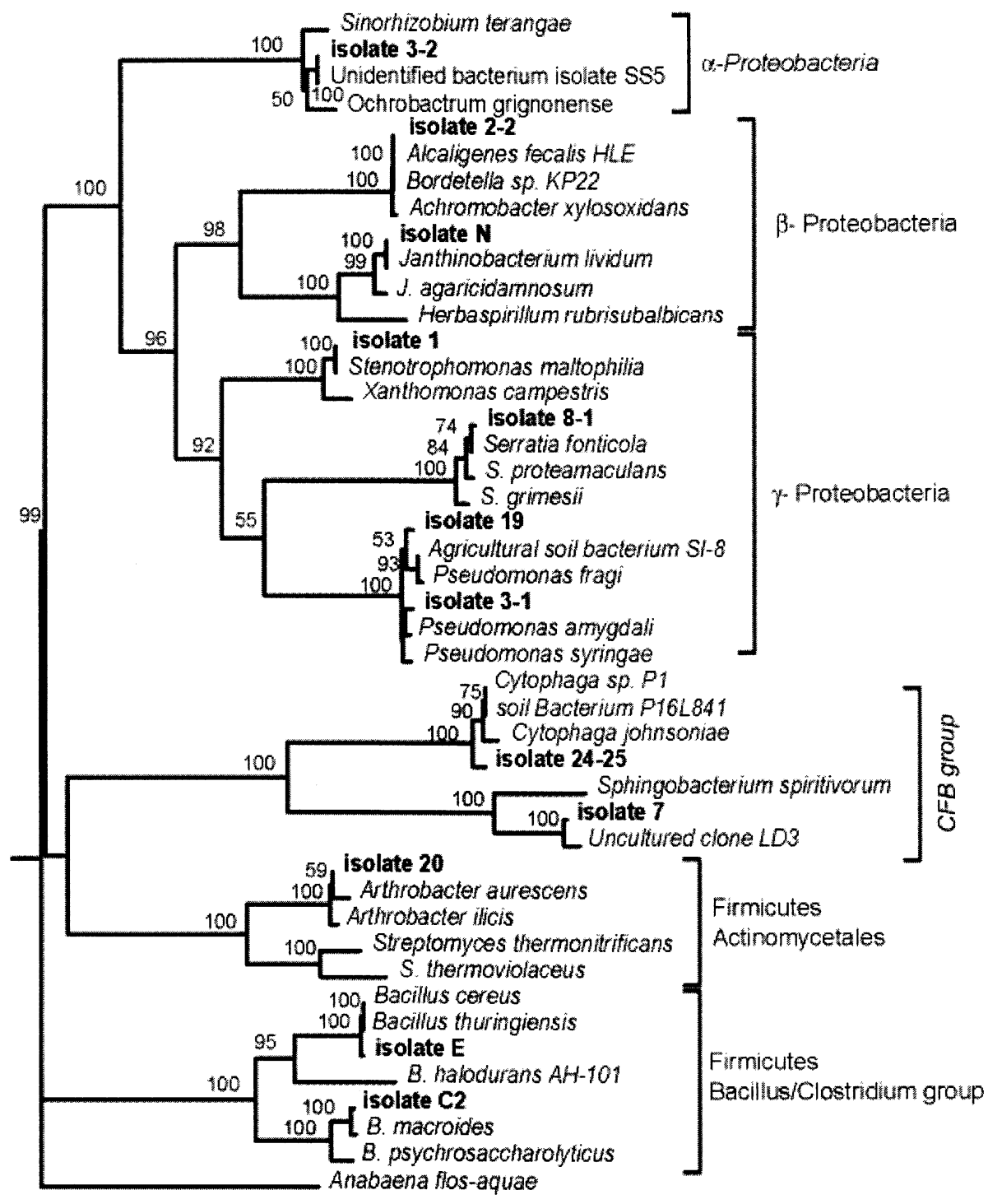

A $\quad 0.045$

$20,24-25,2-2,1,3-1,19,3-2$, and 7. Isolate $\mathrm{N}$, which produced a violet pigment, formed a visible biofilm on the rachis of each replicate feather. We were not able to estimate this attached biomass. Strain 8-1 did not appear to degrade feathers.

\section{Milled Feather Degradation}

Activity of keratinase and concentrations of dissolved protein and amino acid differed among strains (Fig. 4). The highest quantity of proteins was present in the filtrates of strains E, 1, 20 24-25, and J with 19.8 to $9.9 \mu \mathrm{g}$ of protein per $\mathrm{mL}$ (Fig. 4). The culture of the strain 8-1 did not release any detectable dissolved protein after 4 weeks of incubation. For the strains 20, E, and 1, we measured 27.3 to $15.5 \mu \mathrm{g}$ of amino acids per $\mathrm{mL}$ of filtrate (Fig. 4). Strains
Fig. 3. Phylogenetic relationships of the $16 \mathrm{~S}$ rDNA gene fragments sequenced from representative isolates. The bar indicates a Jukes-Cantor distance of 0.02 and bootstrap values greater than $50 \%$ are indicated. (A) Phylogenetic position of isolates $1,2-2,3-1,3-2,7,8$ $1,19,20,24-25, \mathrm{C} 2, \mathrm{E}, \mathrm{N}$; the tree is unrooted with Anabaena flos-aquae. (B) Phylogenetic position of isolates $\mathrm{C} 2, \mathrm{E}$, and $\mathrm{J}$ among the Bacillus genus; the tree is unrooted with Arthrobacter ilicis.

E, 24-25, and J showed the highest keratin azure hydrolysis (1.29 to $0.88 \mathrm{U}$ keratinase per $\mathrm{mL}$ ).

Comparisons between whole and milled feather experiments showed that the percentage of remaining feather was positively correlated with GF/C fragments, proteins, amino acids, and keratinase activities as well as bacterial densities. Keratinase activity was positively correlated with the quantity of proteins; finally amino acid concentrations were positively correlated with protein concentrations and bacterial densities (Table 2).

\section{Discussion}

During the past decade several thermophilic feather-degrading bacteria have been isolated from soils and poultry 


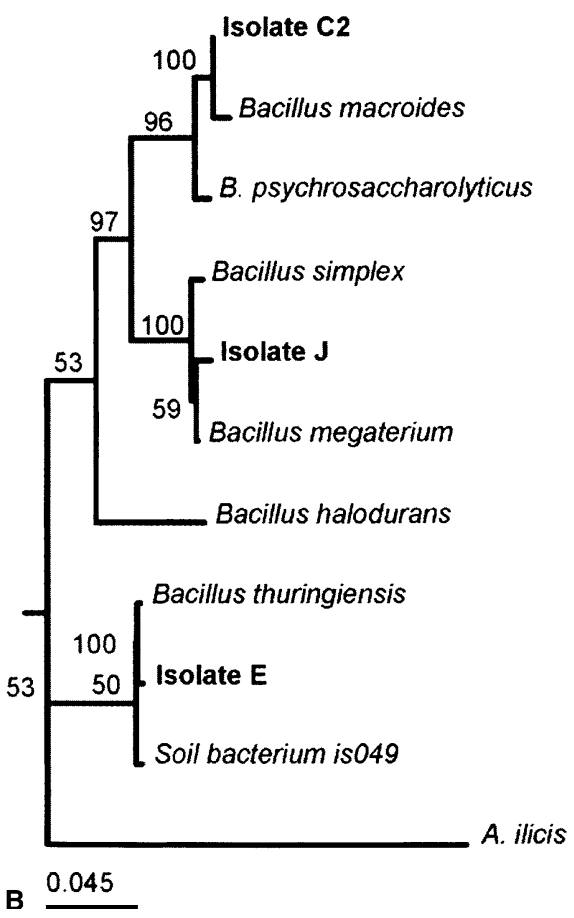

Fig. 3. Continued.

wastes [19]. These isolates are mostly confined to the gram-positives: genera Bacillus and Streptomyces (Table 3). Gram-positive bacteria have already been shown to represent an important part of the soil microbial communities [25]. In our study, we obtained from the meadow soil two Bacillus-related isolates (E and J) demonstrating a high feather-degrading activity at $25^{\circ} \mathrm{C}$. Isolate $\mathrm{J}$ matched closely to Bacillus megaterium. Another feather-degrading B. megaterium has been isolated by EI-Shora et al. [8]. It seems that keratinolysis is commonly found among $\mathrm{Ba}$ cilli. However, Burtt and Ichida [4] isolated from wild birds some Bacillus species that did not show any keratinolytic activity. In our study the Bacillus-related strain C2 showed the weakest keratinolytic activity. We did not isolate any Streptomyces sp., which may result from the fact that Streptomycetes are slow growing and were probably overgrown by other strains. However, strain 20 was related to Arthrobacter sp., which also belongs to the Actinomycetales. Up to now, the genus Arthrobacter had never been associated with keratinolytic activity.

Keratinolysis may not be limited to gram-positive bacteria. Recently, Sangali and Brandelli isolated the Gram-negative Vibrio sp. strain $\mathrm{Kr} 2$ [23] and the Cytophagale Chryseobacterium sp. Kr6 (in press) from a poultry environment; furthermore, Fervidobacterium pennavorans of the order Thermotogales is also a featherdegrader [11]. Our results demonstrate that many other gram-negative bacteria are able to degrade feathers and that there is a high and undescribed diversity among keratinolytic bacteria colonizing abandoned feathers in soil. The keratinolytic function is present in firmicutes as well as in Cytophagales and Proteobacteria.

In our study, the Cytophagale isolate 24-25 showed a significant feather degradation activity. Cytophagales are known to be involved in the degradation of complex macromolecules [26]. Cottrell and Kirchman [6] found

Table 1. Whole feather fragmentation by isolates

\begin{tabular}{|c|c|c|c|c|c|c|}
\hline \multirow[b]{2}{*}{ Isolate } & \multicolumn{2}{|c|}{ Bacteria. $10^{6} \cdot \mathrm{ml}^{-1 \mathrm{a}}$} & \multicolumn{2}{|c|}{$\%$ remaining feather ${ }^{b}$} & \multicolumn{2}{|c|}{$\%$ of $\mathrm{GF} / \mathrm{C}$ fraction $^{\mathrm{c}}$} \\
\hline & Median & Range & Median & Range & Median & Range \\
\hline $\mathrm{C} 2$ & 4 & $1-31$ & 95 & $78-97$ & 1 & $0-4$ \\
\hline $\mathrm{J}$ & 23 & $8-81$ & 80 & 0-94 & 3 & $0-83$ \\
\hline $\mathrm{E}$ & 23 & $9-37$ & 42 & $15-84$ & 42 & $7-69$ \\
\hline 20 & 150 & $134-236$ & 90 & $40-81$ & 2 & $1-11$ \\
\hline $24-25$ & 135 & $46-469$ & 81 & 39-91 & 9 & $3-36$ \\
\hline 7 & 30 & $6-207$ & 94 & $73-96$ & 1 & $0-4$ \\
\hline $3-2$ & 60 & $15-179$ & 93 & $74-96$ & 1 & $0-11$ \\
\hline $\mathrm{N}$ & 20 & $9-35$ & 95 & 89-97 & 1 & $0-4$ \\
\hline $2-2$ & 103 & $65-376$ & 93 & 59-94 & 1 & $0-20$ \\
\hline 1 & 93 & $50-429$ & 92 & 54-94 & 1 & $0-19$ \\
\hline $3-1$ & 61 & $41-201$ & 95 & 90-97 & 1 & $1-2$ \\
\hline 19 & 28 & $20-526$ & 93 & $21-96$ & 1 & $0-47$ \\
\hline $8-1$ & 10 & $4-27$ & 95 & 93-98 & 1 & $0-4$ \\
\hline Control & 0 & $0-0$ & 96 & 95-97 & 0 & $0-1$ \\
\hline
\end{tabular}

\footnotetext{
${ }^{\text {a }}$ Final densities of bacteria.

b percentage of remaining feather.

${ }^{c}$ percentage of feather fragments collected on GF/C membrane.
} 


\section{proteins}

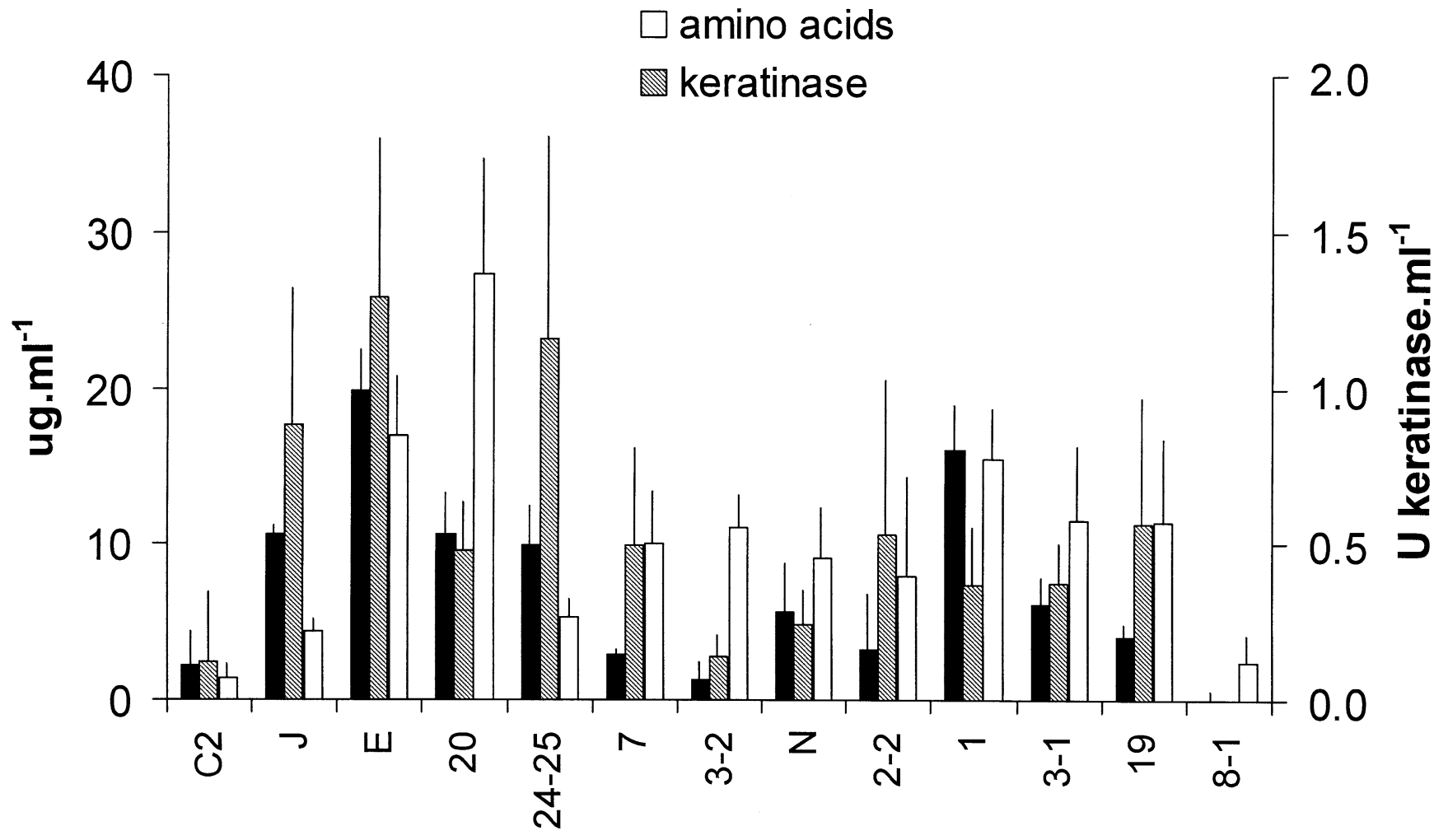

\section{strains}

Fig. 4. Degradation of milled feathers by various strains and release of dissolved proteins ( $\mu \mathrm{g}$ of BSA per $\mathrm{mL}$ ), keratinase activity (units per $\mathrm{mL}$ ), and amino acids ( $\mu \mathrm{g}$ of glycine per $\mathrm{mL}$ ) in the filtrate (average and standard deviation of concentrations of triplicates).

that the Cytophaga-Flavobacteria group accounted for most of the cells consuming proteins and chitin in estuarine and coastal environments.
Our results showed that some Proteobacteria species also degrade feathers: Among the $\gamma$-Proteobacteria, the Stenotrophomonas-related isolate 1 significantly degraded

Table 2. Spearman correlation coefficients between experiments examining whole feather fragmentation versus milled feather degradation

\begin{tabular}{|c|c|c|c|c|c|}
\hline & $\% \mathrm{GF} / \mathrm{C}$ fragments ${ }^{\mathrm{a}, \mathrm{d}}$ & Bacterial densities ${ }^{\mathrm{a}, \mathrm{e}}$ & Proteins $s^{\mathrm{b}, \mathrm{f}}$ & Amino acids ${ }^{\mathrm{b}, \mathrm{g}}$ & Keratinase $^{\mathrm{b}, \mathrm{h}}$ \\
\hline$\%$ remaining feathers ${ }^{\mathrm{a}, \mathrm{c}}$ & $\begin{array}{l}-\mathbf{0 . 6 7 9 9} \\
p=0.008\end{array}$ & $\begin{array}{l}-0.5721 \\
p=0.033\end{array}$ & $\begin{array}{l}-\mathbf{0 . 7 7 1 4} \\
p=0.001\end{array}$ & $\begin{array}{l}-0.5677 \\
p=0.034\end{array}$ & $\begin{array}{l}-0.8779 \\
p<0.001\end{array}$ \\
\hline$\%$ GF/C fragments ${ }^{\mathrm{a}, \mathrm{d}}$ & & $\begin{array}{l}0.3602 \\
p=0.206\end{array}$ & $\begin{array}{l}\mathbf{0 . 6 9 7 6} \\
p=0.006\end{array}$ & $\begin{array}{l}0.3326 \\
p=0.245\end{array}$ & $\begin{array}{l}0.4873 \\
p=0.077\end{array}$ \\
\hline Bacterial densities $^{\mathrm{a}, \mathrm{e}}$ & & & $\begin{array}{l}0.4488 \\
p=0.107\end{array}$ & $\begin{array}{l}0.5837 \\
p=0.028\end{array}$ & $\begin{array}{l}0.4956 \\
p=0.072\end{array}$ \\
\hline Proteins $s^{b, f}$ & & & & $\begin{array}{l}\mathbf{0 . 6 4 0 3} \\
p=0.014\end{array}$ & $\begin{array}{l}\mathbf{0 . 6 6 8 9} \\
p=0.009\end{array}$ \\
\hline Amino acids ${ }^{\mathrm{b}, \mathrm{g}}$ & & & & & $\begin{array}{l}0.4163 \\
p=0.139\end{array}$ \\
\hline
\end{tabular}

Significant correlations are indicated in bold.

${ }^{\mathrm{a}}$ Whole feather experiment.

${ }^{b}$ Milled feather.

${ }^{c}$ Percentage of remaining feather.

${ }^{\mathrm{d}}$ Percentage of fragments collected on GF/C membranes. e Final bacterial densities.

${ }^{\mathrm{f}}$ Protein concentration.

${ }^{\mathrm{g}}$ Amino acid concentration.

${ }^{\mathrm{h}}$ Keratinase activities. 
Table 3. List of feather-degrading isolates and their origins

\begin{tabular}{|c|c|c|}
\hline Organism & Origin & Reference \\
\hline Bacillus licheniformis PWD-1 & Poultry waste & [30] \\
\hline Bacillus licheniformis Carlsberg NCIMB6816 & - & [9] \\
\hline \multirow[t]{3}{*}{ Bacillus licheniformis } & - & [8] \\
\hline & Soil & [15] \\
\hline & Wild bird & {$[4]$} \\
\hline \multirow[t]{3}{*}{ Bacillus subtilis } & Wild bird & [4] \\
\hline & Poultry waste & [14] \\
\hline & Soil & [32] \\
\hline \multirow{2}{*}{ Bacillus pumilus } & Wild bird & [4] \\
\hline & Poultry waste & [9] \\
\hline Bacillus circulans & - & [8] \\
\hline Bacillus megaterium & - & [8] \\
\hline Streptomyces pactum DSM 40530 & Collection culture & [1] \\
\hline Streptomyces fradiae ATCC 14544 & Soil & [18] \\
\hline Streptomyces thermonitrificans MG104 & Agricultural soil & [17] \\
\hline Streptomyces graminofaciens & - & [27] \\
\hline Streptomyces thermoviolaceus SD8 & Lake & [5] \\
\hline Streptomyces albidoflavus S.K1-02 & Hen house soil & [3] \\
\hline Fervidobacterium pennavorans DSM7003 & Hot springs & [11] \\
\hline Vibrio sp. Kr2 & Poultry soil & [23] \\
\hline
\end{tabular}

pigeon feathers. Pseudomonas-related strains 19 and 3-1 were also able to degrade feathers, as well as the $\beta$-Proteobacteria isolate 2-2 (related to the genus Achromobacter). The isolate $\mathrm{N}$, another of the $\beta$-Proteobacteria, showed some keratinolytic activity. No previous work related keratinolytic activities among these genera.

Measurements of whole feather fragmentation were variable. This was probably due to slight structural differences in feathers (stiffness, pigment concentration, degradation by lice, age, and sex of the individuals) which may have interfered with the degradation. Nevertheless, there was a strong negative correlation between dissolved keratinase activities in milled feather medium and percentage of remaining whole feather. This result suggests that the level of whole feather fragmentation could be associated with levels of keratinase activity, although further experiments are required to corroborate the patterns found between these two different sets of experiments.

Most of our isolates seemed to belong to opportunistic species, which do not need keratin to survive in soil. Even if not essential for the individual cell, hydrolysis of highmolecular-weight compounds is an essential first step in the degradation of organic matter in nature [6]. As the primary source of soil protease [29], Bacillus isolates may play a key role in feather recycling. However, one might expect that in the soil feathers are degraded by a consortium of bacteria and fungi, which act in synergy or compete for keratin [19].

This study revealed that the diversity of feather-degrading bacteria is significantly greater than previously described. We showed that keratinolysis was present in phylogenetic groups that had never been associated previously with this function. It also suggests that improved isolation or culture-independent techniques are needed to explore this functional group and its ecological role in the environment. The strains that we obtained in this study should provide a starting point to investigate the distribution and activity of feather-degrading bacteria in soil and on bird plumage.

\section{Acknowledgments}

This work was funded by a subsidy from the "Fondation de Famille Sandoz" to P. Heeb. We thank Jitka Lipka for running our samples at the sequencing facility of the Institute of Ecology University of Lausanne. Pigeons were provided by G. Cuendet. We are grateful to C. Keel and S. Heeb and anonymous reviewers for advice and critical reviews.

\section{References}

1. Böckle B, Galunsky B, Müller R (1995) Characterization of a keratinolytic serine proteinase from Streptomyces pactum DSM 40530. Appl Environ Microbiol 61:3705-3710

2. Boetius A, Lochte K (1994) Regulation of microbial enzymatic degradation of organic-matter in deep-sea sediments. Mar Ecol-Prog Ser 104:299-307

3. Bressollier P, Letourneau F, Urdaci M, Verneuil B (1999) Purification and characterization of a keratinolytic serine 
proteinase from Streptomyces albidoflavus. Appl Environ Microbiol 65:2570-2576

4. Burtt EH, Ichida JM (1999) Occurrence of feather-degrading Bacilli in plumage of birds. Auk 116:364-372

5. Chitte RR, Nalawade VK, Dey S (1999) Keratinolytic activity from the broth of a feather-degrading thermophilic Streptomyces thermoviolaceus strain SD8. Lett Appl Microb 28:131-136

6. Cottrell MT, Kirchman DL (2000) Natural assemblages of marine Proteobacteria and members of the CytophagaFlavobacter cluster consuming low and high-molecularweight dissolved organic matter. Appl Environ Microbiol 66:1692-1697

7. Clayton DH (1999) Feather-busting bacteria. Auk 116:302304

8. El-Shora HM, Ashour SA, Ghanem AA (1993) Purification and characterization of keratinase from $B$. circulans, $B$. licheniformis, and B. megaterium. J Environ Sci, Mansoura University Egypt 6:89-103

9. Evans KL, Crowder J, Miller ES (2000) Subtilisins of Bacillus spp. hydrolyze keratin and allow growth on feathers. Can J Microbiol 46:1004-1011

10. Felsenstein J (1989) PHYLIP—Phylogeny Inference Package (Version 3.2). Cladistics 5:164-166

11. Friedrich AB, Antranikian G (1996) Keratin degradation by Fervidobacterium pennavorans, a novel thermophilic anaerobic species of the order Thermotogales. Appl Environ Microbiol 62:2875-2882

12. Giovannoni SJ, Rappé M (2000) Evolution, diversity and molecular ecology of marine prokaryotes. In: DL Kirchman (ed) Microbial Ecology of the Oceans Wiley-Liss, New York pp 47-84

13. Hwang M, Ederer GM (1975) Rapid hippurate hydrolysis method for presumptive identification of group B Streptococci. J Clin Microbiol 1:114-115

14. Kim JM, Lim WJ, Suh HJ (2001) Feather-degrading Bacillus species from poultry waste. Process Biochem 37:287-291

15. Lin X, Lee C-G, Casale ES, Shih JCH (1992) Purification and characterization of a keratinase from a feather-degrading Bacillus licheniformis strain. Appl Environ Microbiol 58:3271-3275

16. Ludwig W, Strunk O, Klugbauer S, Klugbauer N, Weizenegger M, Neumaier J, Bachleitner M, Schleifer KH (1998) Bacterial phylogeny based on comparative sequence analysis. Electrophoresis 19:554-568

17. Mohamedin AH (1999) Isolation, identification and some cultural conditions of a protease-producing thermophilic Streptomyces strain grown on chicken feather as a substrate. Int Biodeter Biodegr 43:13-21

18. Noval JJ, Nickerson WJ (1959) Decomposition of native keratin by Streptomyces fradiae. J Bacteriol 77:251-263
19. Onifade AA, Al-Sane NA, Al-Musallam AA, Al-Zarban S (1998) Potentials for biotechnological applications of keratin-degrading microorganisms and their enzyme for nutritional improvement of feathers and other keratins as livestock feed resources. Bioresources Technol 66:1-11

20. Osborn AM, Moore ERB, Timmis KN (1999) An evaluation of terminal-restriction fragment length polymorphisme ( $\mathrm{T}$ RFLP) analysis for the study of microbial community structure and dynamics. Environ Microbiol 2:39-45

21. Parry DAD, North ACT (1998) Hard a-keratin intermediate filament chains: substructure of the $\mathrm{N}$ - and C-terminal domains and the predicted structure and function of the Cterminal domains of type I and type II chains. J Struct Biol 122:67-75

22. Sambrook J, Fritsch EF, Maniatis T (1989) Molecular Cloning: A Laboratory Manual. Cold Spring Harbor Laboratory Press, Cold Spring Harbor, NY

23. Sangali S, Brandeli A (2000) Feather keratin hydrolysis by a Vibrio sp. strain Kr2. J Appl Microbiol 89:735-743

24. Santos RMDB, Firmino AAP, de Sá CM, Felix CR (1996) Keratinolytic activity of Aspergillus fumigatus Fresenius. Curr Microbiol 33:364-370

25. Sessitsch A, Weilharter A, Gerzabek MH, Kirchmann H, Kandeler E (2001) Microbial population structures in soil particle size fractions of a long-term fertilizer field experiment. Appl Environ Microbiol 67:4215-4224

26. Shewan JM, McMeekin TA (1983) Taxonomy (and ecology) of Flavobacterium and related genera. Annu Rev Microbiol 37:233-252

27. Szabo I, Benedek A, Szabo IM, Barabas G (2000) Feather degradation with a thermotolerant Streptomyces graminofaciens strain. World J Microb Biot 16:253-255

28. Vaneechoutte M, Rossau R, Gillis M, Janssens D, De Paepe T, Fiers T, Claeys G, Kersters K (1992) Rapid identification of bacteria of the Comamonadaceae with amplified ribosomal DNA-restriction analysis (ARDRA). FEMS Microbiol Lett 93:227-233

29. Watanabe K, Hayano K (1995) Seasonal variation of soil protease activities and their relation to proteolytic bacteria and Bacillus spp. in paddy field soil. Soil Biol Biochem 27:197-203

30. Williams CM, Richter CS, MacKenzie Jr JM, Shih JCH (1990) Isolation, identification and characterization of a featherdegrading bacterium. Appl Environ Microbiol 56:1509-1515

31. Williams CM, Lee CG, Garlich JD, Shih JCH (1991) Evaluation of a bacterial feather fermentation product, feather-lysate as a feed protein. Poult Sci 70:85-94

32. Zaghloul TI, Al-Buhra M, Al-Azmeh H (1998) Isolation, identification and keratinolytic activity of several featherdegrading bacterial isolates. Appl Biochem Biotechnol 7072:207-213 